JIIP: Jurnal IImiah IImu Pemerintahan

Volume 5, Nomor 2, Tahun 2020

DOI: 10.14710/jiip.v5vi2.8375

\title{
Politik Jalanan: Fenomena Perilaku Politik Gerakan Pemuda Ka'bah Kota Yogyakarta di Pemilu Serentak 2019
}

\author{
Moch. Edward Trias Pahlevi ${ }^{1}$, David Efendi ${ }^{2}$, \& Azka Abdi Amrurobbi ${ }^{3}$ \\ 1,2 Magister Ilmu Pemerintahan, Universitas Muhammadiyah Yogyakarta \\ ${ }^{3}$ Magister Politik Pemerintahan, Universitas Gadjah Mada
}

\begin{abstract}
INTISARI
Penelitian ini dilatarbelakangi oleh opini masyarakat yang menganggap bahwa Gerakan Pemuda Ka'bah (GPK) memiliki tendensi kelompok kekerasan dan kepentingan politik praktis, khususnya yang berafiliasi pada Partai Persatuan Pembangunan (PPP). Kehadiran kelompok ini disebut sebagai kelompok vigilante atau milisi yang dianggap oleh masyarakat sebagai kelompok kekerasan terutama di jalanan. Artikel ini bertujuan untuk melihat bagaimana manuver politik GPK selama momentum pemilu 2019 yang lalu. Penelitian ini merupakan penelitian lapangan yang mengkaji tentang perilaku politik dan politik jalanan. Lokasi penelitian dilakukan di Kota Yogyakarta dengan mengunakan metode penelitian kualitatif, yang mengandalkan data-data primer dari para informan. Hasil penelitian ini menunjukkan bahwa perilaku GPK dalam politik jalanan dan eksistensi simbol ternyata berkorelasi dengan kepentingan ekonomi mereka. Selain itu, munculnya GPK Khittah berdampak pada menurunnya suara pemilih PPP di Kota Yogyakarta.
\end{abstract}

\section{KATA KUNCI}

Gerakan Pemuda Ka'bah; kelompok vigilante; pemilu; perilaku politik; politik jalanan

\section{Pendahuluan}

D asca runtuhnya rezim Soeharto ciri yang paling menonjol di Indonesia adalah maraknya kelompok-kelompok kekerasan berbasis identitas di tengah masyarakat. Biasanya kelompok tersebut hadir dengan memanfaatkan ketidakstabilan negara dalam mengatur politik keamanan masyarakat. Mereka tidak saja mengisi ruang publik dengan aksi-aksi di jalan raya sambil melancarkan berbagai tuntutan. Lebih dari itu, dengan memanfaatkan 'angin demokratisasi' tak sedikit diantara para dedengkotnya yang berhasil masuk dijabatan formal pemerintahan.

Korespodensi:

Magister Ilmu Pemerintahan, Universitas Muhammadiyah Yogyakarta, Jl. Brawijaya, Kasihan, Bantul, Yogyakarta 55183

Email: mochedwaardtriaspahlevi@gmail.com 
Geliat para kelompok kekerasan ini menarik untuk diperhatikan. Di masa kini, perannya seolah telah mengunci peran negara dalam pengaturan politk keamanan di tengah masyarakat. Kelompok keamanan ini hadir dalam aneka variasi dan perwujudan lokal: ormas-ormas Vigilante, milisi, geng-geng, pemeras, centeng, penjahat kecil, preman politik, dan keamanan swasta.

Berbagai kelompok vigilante, milisi, geng-geng ternyata menjadi perhatian berbagai pihak ketika menjelang pemilihan baik pemilihan legislatif, pemilihan presiden, hingga pemilihan kepala daerah. Kepala polisi di berbagai daerah mengantisipasi dampak keterlibatan kelompok milisi ataupun vigilante terhadap gangguan keamanan dan mengadakan pertemuan secara teratur dengan berbagai milisi elit untuk koordinasi. Keterlibatannya dalam politik dengan menunjukkan dukungan kepada salah satu kandidat saat mereka menghadapi tantangan saingan oganisasi (kontestasi) dalam perlombaan perlindungan negara.

Di Pemilu Serentak 2019 Gerakan Pemuda Ka'bah melakukan manuver politik dengan mendeklarasikan GPK Khittah. GPK Khittah merupakan gerakan Politik Gerakan Pemuda Ka'bah dalam mengosongkan gerbong atau dukungan kepada Partai Persatuan Pembangunan, Gerakan Pemuda Ka'bah selama ini menjadi basis suara pemilih muda bagi Partai Persatuan Pembangunan. Tentunya GPK Khittah ini berdampak pada menurunnya suara Partai Persatuan Pembangunan di Kota Yogyakarta bahkan di DIY. Pemicu terjadinya manuver politik ini disebabkan dualisme kepemimpinan partai PPP di Pusat. Serta dukungan PPP pusat kepada pasangan Jokowi-Maruf dianggap tidak pro terhadap kepentingan umat Islam.

Penelitian ini akan membahas salah satu kelompok vigilante atau milisi yang memiliki keterikatan dengan partai politik Partai Persatuan Pembangunan yaitu Gerakan Pemuda Kab'ah Kota Yogyakarta. Kehadiran Gerakan Pemuda Kab'ah menarik banyak perhatian masyarakat. Mereka biasa diidentikan oleh masyarakat sebagai sebuah kelompok yang memiliki tendensi kekerasan. Serta kerap terlibat dalam kejadian kekerasan antar kelompok yang berbeda.

Secara nasional, GPK didirikan di Jakarta sejak April 1982. GPK (Gerakan Pemuda Ka'ba) adalah milisi sipil terbesar di Yogyakarta. GPK juga merupakan gerakan underbow kaum muda yang mendukung PPP (Partai Pembangunan Bersatu). GPK di provinsi Yogyakarta adalah yang terbesar dibandingkan gardu lainnya, karena ada 3000 anggota formal GPK di wilayah ini. Sementara milisi sipil lainnya hanya memiliki sekitar 50-700 anggota. Sebagian besar anggota GPK tinggal di empat desa Islam yang dikenal sebagai 4K, Kauman, Karangkajen, Kotagede dan Kuncen, ditambah desa Islam lainnya, yaitu Notoprajan. Kelompok milisi ini di antara orang-orang menjadi kelompok yang sering membuat keributan di jalan raya. Aksi sweeping, kekerasan bagi kelompok yang berbeda pendapat dengan GPK, aksi kekerasan oleh kelompok milisi GPK untuk mencari keberadaan (Laksono, Brata, Ertanto, Riomandha, \& Gunawan, 2000).

Gerakan Pemuda Ka'bah (GPK) kepopulerannya didalam masyarakat sudah lama dikenal dan tidak asing lagi di telinga masyarakat. Mereka terkenal dengan keberanian bertarung fisik yang tidak diragukan lagi pada beberapa persitiwa. Beberapa aksi seperti konvoi, sweeping penjual miras, beberapa tempat prostitusi liar, bentrok fisik dengan kelompok lain yang melibatkan masa. Tindakan yang mereka lakukan selama ini menjadi sangan menarik untuk dikaji, karena kegiatan mereka tidak hanya pada musim pemilu 
ataupun pilkada lima tahunan. Kegiatan mereka terjadwal dari kegiatan mingguan hingga lima tahunan. Salah satu agenda yang dilakukan adalah perekrutan serta penguatan anggota yang dibarengkan dengan menyelenggarakan agenda-agenda politik (Saputro, 2016).

Menurut Yasih (2015) masing-masing anggotannya mempunyai orientasi yang beragam ada yang memang menyalurkan afilisasi politik lewat PPP mencari dukungan di Gerakan Pemuda Ka'bah, ada yang mencari identitas politik seorang muslim, hobi berkelahi, hingga mencari nafkah (ekonomi). Sehingga orientasi yang kompleks, berbagai tujuan tersebut terkadang harus diperebutkan, walaupun harus berhadapan dengan kelompok yang lain. Dalam penelitian yang dilakukan oleh International NGO Forum and Development (Infid) menjelaskan sejarah kelompok-kelompok kekerasan yang berlabel partai politik di jalanan seperti Gerakan Pemuda Ka'bah. Kelompok ini sering membuat kekacauan di jalan raya dengan menunjukan eksistensi sebagai kelompok islam dalam melawan kemungkaran. Kelompok ini menjadi aset politik bagi para elite partai politik dalam memenangkan pertarungan politik baik pileg,pilpres, dan pilkada (O’neil \& Domingo, 2016).

Kelompok-kelompok milisi bersimbol keagamaan di Indonesia sangat banyak dan kerap kali melakukan tindakan kekerasan dalam menjalakan aksi politiknya. Menurut Wilson (2018) memaparkan embrio Laskar Islam Radikan fudamentalis di Indonesia hingga latar belakang terbentuknya Front Pembela Islam. Gerakan ini memandang agama yang dimaksud di sini adalah agama yang tersermin dalam realitas sosial, yang membentuk suatu interaksi, gerakan dan kontruksi sosial.

Menurut Saputro (2016) melakukan penelitian lapangan untuk politik jalanan dan pemuda: studi tentang Gerakan Pemuda Ka'bah di Yogyakarta. Penelitian ini menjelaskan perilaku GPK dalam tindakan kekerasan seperti sweeping tempat prostitusi,dan melakukan serangan kepada kelompok LGBT dan perilaku politik yang sering membuat kekacauan di masyarakat sesgguhnya untuk kepentingan jasa keamanan yang memiliki tujuan pendapatan ekonomi.

Dari hasil penelitian terdahulu diatas penelitian terdahulu peneliti belum menemukan sebuah kajian yang menganalisa prilaku politik Gerakan Pemuda Ka'bah yang berazaskan simbol keagamaan dalam perhelatan demokrasi yaitu pemilu. serta belum adanya kajian yang menjelaskan secara detail orientasi politik Gerakan pemuda Ka'bah yang bertujuan pada kepetingan ekonomi melalui jasa keamanan dan penguasaan lahan parkir Penelitian ini akan menjelaskan aksi dan tindakan politik jalanan Gerakan Pemuda Kabah Kota Yogyakarta yang berhubungan dengan Prilaku Kekerasan yang berdampak pada kepetingan ekonomi seperti pengelolaan lahan parkir, jasa keamanan. Dan eksitensi simbol sebagai gerakan populis untuk memunculkan hubungan patronase antar elite. serta Gerakan Politik Gerakan Pemuda Ka'bah dalam mewarnai Politik elektoral di Kota Yogyakarta khususnya pada pemilu serentak 2019.

Dalam menganalisa fenomena yang diteliti, peneliti setidaknya mendasarkan analisa itu dari beberapa konsep dan teori dirujuk. Penggunaan konsep dan teori ini untuk memperkuat dasar teoritis dari riset ilmiah ini. Beberapa teori yang di rujuk adalah prilaku politik dan kelompok vigilante. 
Prilaku Politik Gerakan Pemuda Ka'bah di Kota Yogyakarta berdampak pada orientasi kekerasan di jalanan dan sebagai perwujudan eksistensi serta untuk mendapatkan kepentingan ekonomi. Prilaku politik yang dilakukan Gerakan Pemuda Kabah lebih dominan kepada politik jalanan dibandingkan perebutan kekuasaan dalam pemilu.

Menurut Surbakti (2010) bahwa perilaku politik adalah kegiatan yang berkenaan dengan proses pembuatan keputusan politik. prilaku politik identik dengan sebuah tindakan yang dilakukan untuk mempengaruhi seseorang dan menghasilkan sebuah kebijakan. Perilaku politik meliputi tanggapan internal seperti persepsi, sikap, orientasi dan keyakinan serta tindakan-tindakan nyata seperti pemberian suara, protes, lobi dan sebagainya. Persepsi politik berkaitan dengan gambaran suatu obyek tertentu, baik mengenai keterangan, informasi dari sesuatu hal, maupun gambaran tentang obyek atau situasi politik dengan cara tertentu (Heywood, 2007).

Perilaku Politik Suatu tindakan dan keputusan politik tidak hanya ditentukan oleh fungsi (tugas dan wewenang) yang melekat pada lembaga yang mengeluarkan keputusan (sedangkan fungsi itu sendiri merupakan upaya mencapai tujuan masyarakat, negara atau nilai-nilai politik), tetapi juga dipengaruhi oleh kepribadian (keinginan dan dorongan, persepsi dan motivasi, sikap dan orientasi, harapan dan cita-cita, ketakutan dan pengalaman masa lalu) individu yang membuat keputusan tersebut (Budiardjo, 2010). Jadi perilaku politik adalah kegiatan-kegiatan yang dilakukan oleh seseorang individu atau kelompok untuk melakukan sebuah gerakanyang berdampak pada keputusan politik atau kebijakan politik yang berdampak pada masyarakat luas.

Sedangkan untuk konseptualisasi kelompok vigilante, Gerakan Pemuda Ka'bah dikenal publik sebagai kelompok memiliki orientasi kekerasan dalam tindakan politik jalanan. Aksi-aksi kekerasan dalam melakukan sweeping, perebutan wilayah, serta konflik antar kelompok lain mencitrakan bahwa Gerakan Pemuda Ka'bah sebagai sebuah kumpulan Vigilante.

Kelompok vigilante adalah kelompok-kelompok yang rnengangkat diri mnereka sendiri sebagai pihak yang berwenang mnenerapkan pemberlakuan hukum. Kelompok ini kerap mengambil kewenangan negara dalam melakukan perlindungan keamanan bagi para klien (Colombijn, 2002).

Kelompok Vigilante adalah pertama merupakan kelompok pelaku kekerasan; kemudian kelompok vigilante bangkit berlandaskan ketidakpercayaan masyarakat terhadap kinerja aparat penegak hukum; ketiga sifat masyarakat yang otonom dan merasa bertanggung jawab atas penegakan hukum maupun tatanan sosial yang telah ada (Buur \& Jensen, 2004).

Jadi Kelompok vigilante secara garis besar dapat disebutkan sebagai kelompok kekerasan yang mengambil kewenangan aparat hukum dalam menegakan hukun. Kelompok ini melakukan tindakan kekerasn akibat dari ketidakpercataan masyarakat terhadap aparat penegakan hukum. Prilaku ini sangat tercemin pada Gerakan Pemuda Ka'bah, yang kerap kali mengambil keweangan negara dalam melakukan tindakan kekerasan yang seharusnya kewenangan melakukan tindakan itu ialah negara. 
Penelitian ini dilakukan dengan mengunakan pendekatan kualitatif. Menurut Creswell (2016) penelitian kualitatif merupakan metode-metode untuk mengeksplorasi dan memahami makna yang oleh sejumlah individu atau sekelompok orang dianggap berasal dari masalah sosial atau kemanusiaan. Sumber data dari penelitian ini terdiri dari sumber data primer dan sekunder. Sumber data primer diperoleh dari hasil pengamatan (observasi) dan wawancara, dimana wawancara dilakukan kepada sejumlah key informant yang terdiri dari komponen pimpinan Gerakan Pemuda Ka'bah di Kota Yogyakarta dan para anggota simpatisan Gerakan Pemuda Ka'bah. Pemilihan informan didasarkan pada teknik purposive, yaitu teknik pengambilan informan didasarkan dengan pertimbangan tertentu, seperti mengetahui kondisi internal Gerakan Pemuda Ka'bah dan kegiatan-kegiatan yang dilakukan Gerakan Pemuda Ka'bah. Data-data yang kemudian diperoleh pada tahapan selanjutnya divalidasi dengan menggunakan teknik triangulasi data, dimana peneliti mencari kesesuian informasi atas satu hal yang ditanyakan kepada beberapa informan. Data yang telah di seleksi dan divalidasi kemudian masuk pada tahapan analisa.

\section{Relasi Politik Jalanan dan Kepentingan Ekonomi}

Eksistensi dalam bahasa Latin adalah kemunculan atau keberadaan itu nyata, keberadaan dalam perspektif simbol-simbol politik adalah suatu keharusan bagi kelompok, untuk menunjukkan eksistensinya di tengah-tengah masyarakat. Konteks keberadaan politik simbol diperlukan untuk setiap organisasi partai atau organisasi sosial. Menurut Satrawati disebutkan bahwa keberadaan simbol merupakan tuntutan dari setiap organisasi untuk memberikan penanaman pemikiran publik tentang keberadaan masing-masing organisasi dan digunakan untuk menarik simpati publik (Efriza, 2019).

Kekuatan basis masa yang cukup besar di miliki Oleh Gerakan Pemuda Ka'bah tidak lepas dengan sosok figur di dalam tubuh kelompok ini. Peran elite kepemimpinan Gerakan Pemuda Ka'bah Yogyakarta sangat kuat dalam mempengaruhi kader GPK dalam kebijakan apa pun. Khusus untuk kader muda Gerakan Pemuda Ka'bah sangat menghormati tokoh-tokoh GPK seperti Syukri Fadholi, Muhammad Fuad, Deny, Rubi. Nama-nama ini menjadi tokoh sentral bagi kader Gerakan Pemuda Ka'bah Yogyakarta dalam menentukan arah kebijakan kelompok ini. Ketiga tokoh ini adalah Muhammad Fuad, Deny, Ruby, seorang tokoh yang dihormati di antara anggota Gerakan Pemuda Ka'bah yang bermarkas di Parkir Ngabean di Yogyakarta. Menurut hasil wawancara penulis terhadap salah satu pimpinan tokoh muda Gerakan Pemuda Ka'bah(GPK) Kota Yogyakarta yaitu Arif Arjani. Ada pembagian peran dari ketiga tokoh ini yaitu:

1. Muhammad Fuad Memiliki fungsi sebagai menjaga hubungan urusan dengan elite politik dan juga mengurusi hal-hal birokrasi pemerintahan.

2. Deni sebagai ketua Gerakan Pemuda Ka'bah mengambil peran untuk memperkuat kekuatan anggota Gerakan Pemuda Ka'bah sehingga satu komando

3. Rubi mengelola area parkir di Ngabean Yogyakarta

4. Syukri Fadholi merupakan pembina Gerakan Pemuda Ka'bah yang juga menjadi sosok sentral sebagai penganyom atau sosok ayah dalam tubuh internal Gerakan Pemuda Ka'bah 
Keempat tokoh ini menjadi sosok sentral dalam tubuh internal Gerakan Pemuda Ka'bah dan menjadi rujukan bagi para simpatisan Gerakan Pemuda Ka'bah di Kota Yogyakarta. Rujukan yang dimaksud salah satunya ialah rujukan dukungan politik baik di pemilihan umum legislatif dan eksekutif ataupun kepala daerah.

Keberadaan Gerakan Pemuda Ka'bah memiliki respons positif dan negatif. Menurut temuan lapangan dalam agenda kampanye parade tauhid atau konvoi yang dilakukan oleh Gerakan Pemuda Ka'bah bertujuan untuk menginformasikan kepada publik bahwa Islam memiliki pasukan yang rela mati dalam membela agama. Dalam menunjukkan simbol-simbol Ka'bah memberikan informasi bahwa umat Islam harus bersujud menghadap Ka'bah. Dalam wawancara dengan komanda Gerakan Pemuda Ka'bah Jetis Kota Yogyakarta yang dilakukan oleh penulis bahwa Parade tauhid atau konvoi ini adalah tugas untuk mempertahankan Islam dan menegakkan Amar Ma'ruf Nahi Mungkar. Parade Tauhid dengan ratusan sepeda motor dengan mengibarkan bendera Ka'bah bangga karena merupakan salah satu cara untuk menginformasikan kepada semua warga bahwa keberadaan kelompok ini menegakkan Amar Ma'ruf Nahi Mungkar. Fanatisme adalah fenomena yang terjadi pada simpatisan dan kader GPK

Gerakan Pemuda Ka'bah memiliki jargon dengan sebutan satu komando, istilah yang membuat loyal di hati para kader Gerakan Pemuda Ka'bah dan simpatisannya. Ketika para pemimpin Gerakan Pemuda Ka'bah melakukan instruksi maka semua anggota akan mengikuti arahan pemimpin. Peran elit Gerakan Pemuda Ka'bah ini menjadi pengaruh yang sangat besar dalam merayu simpatisan untuk melakukan tindakan seperti menyapu. Ambil tindakan terhadap LGBT, dan parade tauhid. Satu baris perintah dapat membakar kader dan simpatisan GPK dalam melakukan kegiatan GPK, efek kalimat dapat memengaruhi perilaku dan tindakan organisasi.

Tindakan kelompok ini memiliki kesan negatif pada masyarakat Yogyakarta. Salah satunya adalah salah satu aktivis Elanto di Yogyakarta yang menulis di media sosial mengatakan bahwa Underbouw Partai ini tidak dapat memberikan pendidikan yang baik bagi masyarakat. Ini mendapat respons yang kuat dari simpatisan dan anggota Gerakan Pemuda Ka'bah. Pendapat publik yang negatif ini didasarkan pada perilaku dan tindakan GPK yang pernah melakukan tindakan kekerasan. Stigma adalah atribut yang sangat luas yang dapat membuat individu kehilangan kepercayaan diri dan bisa menjadi hal yang menakutkan.

Dengan menunjukan atribut bersimbol islam dan memiliki kader yang begitu banyak, tentu ini menjadi daya tarik politik bagi para pemangku kepentingan. Kekerasan yang dilakukan oleh Gerakan Pemuda Ka'bah bermotif ekonomi seperti penguasaan lahan parkir di wilayah ngabean Kota Yogyakarta. Dalam fenomena Gerakan Pemuda Ka'bah dalam memperoleh wilayah kekuasaan disebabkan oleh faktor ekonomi dan didapatkan melalui proses tendensi kekerasan dalam perebtan wilayah. Kekerasan fisik menjadi cara untuk mendapatkan lahan parkir di Kota Yogyakarta dan juga jasa keamanaan. Berikut skema pemetaan kekerasan dalam memperebutkan lahan parkir 
Tabel 1. Pemetaan Kekerasan dalam Memperebutkan Lahan Parkir

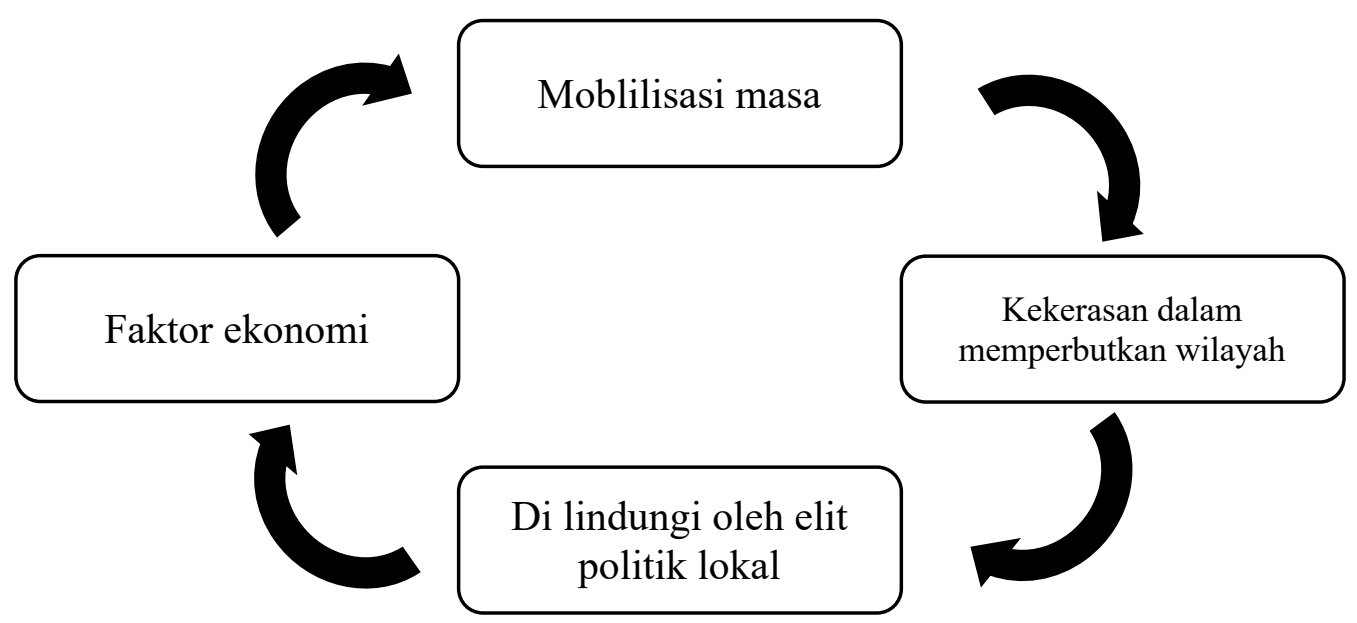

Sumber: diolah oleh penulis

Dari analisis gambar diatas faktor ekonomi menjadi dasar tindakan kekerasan kelompok ini terjadi. Dalam temuan penulis dalam melakukan wawancara, proses mendapatkan tempat parkir di daerah ngabean menggunakan kekerasan terhadap simpatisan PDIP di Yogyakarta. Proses ini menunjukkan bahwa GPK adalah salah satu kelompok yang merebut kekuasaan dengan proses kekerasan. Karena itu, simpatisan PDIP dengan simpatisan PPP selalu berselisih berdasarkan kepentingan organisasi dan orang tersebut. Kekerasan yang terjadi telah mengakibatkan banyak korban meninggal dunia akibat konflik dua kelompok GPK dengan simpatisan PDIP.

Dalam insiden kekerasan antara simpatisan GPK dan PDIP dapat dianalisis, kekerasan antara pihak-pihak di bawah tidak berhenti tetapi memburuk dan lebih buruk. Era reformasi semakin menjadikan gangster, preman atau kelompok milisi lebih kuat dalam melakukan kekerasan di wilayah tersebut. Ketika tatanan kekerasan baru dikendalikan oleh Soeharto, sekarang tidak terkendali untuk mencari kepentingan pribadi atau kelompok utama penyebabnya adalah ekonomi. Kelompok-kelompok milisi ini dilindungi oleh elit politik di daerah masing-masing. Tindakan prilaku politik jalanan ini berdampak pada pandangan masyarakat secara umum Gerakan Pemuda Ka'bah merupakan sebuah kelompok preman dengan jubah simbol keagamaan.

Perebutan wilayah menjadi tujuan untuk mendapatkan penghasilan baik untuk kepentingan kelompok dan menghidupi para anggota atau simpatisan Gerakan Pemuda Ka'bah. Sebagian besar mata pencaharian anggota Gerakan Pemuda Ka'bah adalah petugas parkir dan jasa keamanan mereka merasa para pemimpin Gerakan Pemuda Ka'bah telah memberikan anggota Gerakan Pemuda Ka'bah untuk mendapatkan uang. Menurut kenyataan di lapangan salah satu faktor yang bergabung dengan Gerakan Pemuda Ka'bah adalah masalah ekonomi. Ada beberapa anggota yang tidak memiliki pekerjaan setelah bergabung dengan Gerakan Pemuda Ka'bah mereka untuk menjadi petugas parkir atau jasa keamanan dan dapat menghidupi keluarga mereka. Lahan parkir yang dimiliki oleh Gerakan Pemuda Ka'bah Kota Yogyakarta salah satu contoh nya 
ialah parkir ngabean Kota Yogyakarta. Serta memiliki tugas sebagai jasa keamanan saat acara perayaan Skaten di Kota Yogyakarta.

Kedekatan Gerakan Pemuda Ka'bah dengan para elit politik pejabat pemerintah di Yogyakarta tercermin dari beberapa kepercayaan yang diberikan pada kelompok ini oleh pihak elite politik lokal. misalnya mengendalikan lahan parkir, acara skaten, dan penguasaan wilayah pendestrian di Alun-alun Utara. Hubungan dengan elite lokal di DIY terjadinya hubungan patron-klien atau patronase yang tidak bisa dihindarkan. Keduanya memiliki kepentingan bersama. Elite politik memerlukan jasa keamanan dari kelompok Gerakan Pemuda Ka'bah, sedangkan pihak Gerakan Pemuda Ka'bah membutuhkan perlindungan aturan hukum dalam mengontrol lahan-lahan parkir serta jasa keamanan di kota Yogyakarta.

Penguasaan wilayah parkir dan jasa keamanan "perlindungan" biasanya dianggap perkerjaan yang cocok bagi mereka yang moda sosial utamanya adalah keahlian dalam penggunaan kekerasan. Logika ini mereproduksi pola hubungan negara dan kelompok ini di mana keduanya mendapatkan keuntungan bersama. dengan cara hubungan ini organisasi bisa mudah mendapatkan akses-akses politik dari para elite politik lokal dalam mendapatkan keuntungan ekonomi. Gerakan Pemuda Ka'bah memiliki kekuatan pengaruh politik yang besar dan selalu menjadi objek perlindungan bagi elite atau politisi, perlindungan ini terjadi antara elite politik dan elite Gerakan Pemuda Ka'bah yang akan mempengaruhi simpatisan Gerakan Pemuda Ka'bah dalam bentuk layanan keamanan, parkir dan yang terkait dengan mata pencaharian. Perlindungan ini menghasilkan cara berpikir simpatisan GPK mengikuti instruksi kepemimpinan Gerakan Pemuda Ka'bah dalam pemilihan eksekutif dan legislatif. Lebih tepatnya hubungan timbal balik yang diberikan kepada para elite politik lokal ini berupa bentuk dukungan politik dalam pemilihan umu ataupun pemilihan kepala daerah.

Prilaku politik jalanan yang dilakukan oleh Gerakan Pemuda Ka'bah berdampak pada terjadinya hubungan patronase antara elite GPK dan juga elite politik lokal. Hubungan Patronase merupakan hubungan hal yang dianggap biasa di Indonesia, patronase adalah pembagian keuntungan di antara politisi untuk mendistribusikan sesuatu secara individual kepada pemilih, pekerja atau juru kampanye dalam mendapatkan dukungan politik dari mereka (Berenschot, 2018). Hubungan ini yang membuat kondisi politik di Indonesia tidak berkembang. Faktor uang menjadi pemenang dalam proses pemilihan legislatif dan eksekutif. Hubungan patron-klien ini akan selalu dipertahankan antara elite politik dan kelompok masyarakat maupun kelompokkelompok yang memiliki basis kekuatan masa yang besar.

Fenomena ini dalam pandangan I. D. Wilson (2015) disebut sebagai istilah "jatah preman" bisa dimaknai sebagai hubungan di mana kekuatan koersif dan intimidasi dipakai untuk meraih uang, sumber daya, atau kekuasaan dengan dalih menawarkan jasa pengamanan dari ancaman eksternal. Negara berfungsi sebagai legitimasi dalam tindakan yang dilakukan oleh para kelompok kekerasan atau para kelompok penguasa wilayah.

Dalam kondisi seperti ini di mana kehadiran negara sebagai tangan-tangan kelembagaan negara praktis hanya bisa hadir secara parsial, kelompok-kelompok kekerasan yang secara teritorial bersifat lokal bisa menjadi "sekutu" alamiah untuk memperkuat kekuasaan negara dan menjaga bentuk-bentuk tantanan yang disepakati 
pada tingkat lokal, beroperasi seperti waralaba kekuasaan negara (Centeno \& Portes, 2006).

Dalam analisis penelitian ini keberadaan simbol adalah kegiatan yang biasa dilakukan dalam suatu kelompok, organisasi masyarakat, partai, dan LSM tetapi patronase akan menciptakan masalah dalam hal demokrasi di Indonesia. Pelindung adalah orang yang memegang kekuasaan, dan memimpin implementasi kebijakan. Klien diidentifikasi sebagai pengikut setia, pekerja birokrasi yang mematuhi aturan pelindung. Dalam analogi lain, pelindung adalah tuan (bos), dan klien adalah bawahan. Perlindungan akan mengarah pada budaya kepatuhan, rasa hormat, kepercayaan, dan loyalitas kepada para penguasa sehingga semua yang dipesan dan diminta dari pelindung klien akan dipatuhi. Dinamika patronase ini akan menciptakan sistem demokrasi yang belum matang di Indonesia. Masyarakat, organisasi masyarakat, LSM dan individu yang menerima hasil perlindungan akan mengalami fase tidak adanya kekuatan kritis untuk mengkritik pemerintah ketika pihak berwenang salah dalam pembuatan kebijakan.

Bentuk tindakan Gerakan Pemuda Kabah ini untuk memperjuangkan eksistensi dan identitas simbol politiknya di masyarakat Yogyakarta mencakup beberapa isu. Mulai dari politik, sumber ekonomi sampai dengan isu keagamaan. Pada wilayah politik Gerakan Pemuda Ka'bah selalu aktif ketika penyelenggaraan pemilu baik legislatif dan eksekutif. Di pemilu 2019 Gerakan Pemuda Ka'bah membentuk deklarasi yang dinamai GPK Khittah. GPK Khittah ini sebuah deklarasi bahwa kelompok ini tetappada khittah perjuangan islam dalam membela amar mahruf nahi mungkar. Dan memberikan dukungannya kepada salah satu pasangan calon presiden. Dari sisi legislatif Gerakan Pemuda Ka'bah tidak terlibat untuk menjadi bagian calon legislatif dikarenakan terjadinya dualisme di tubuh Partai persatuan pembangunan. Maka Gerakan Pemuda Ka'bah untuk mengambil sikap kembali kepada khittah islam. Kemudian pada isu ekonomi mereka terlibat dan dapat mengelola beberapa sumber-sumber ekonomi yang ada pada wilayah Kota Yogyakarta, seperti pengelolaan lahan parkir, lapak-lapak sekaten, jasa keamanan. Pada isu agama pun mereka juga terlibat aktif seperti parade tauhid, gerakan anti Syi'ah, Sweeping tempat maksiat. Tindakan-tindakan mereka ini bagian untuk menunjukan eksistensi simbol islam kepada masyarakat luas.

Tindakan mereka memberikan semangat kepada sebagian masyarakat, minimal pada anggota Gerakan Pemuda Ka'bah untuk senantiasa menjaga kehormatan martabat agama Islam, seperti penolakan tentang legitimasi Lesbi, Biseksual, Gay, Trans Gender (LGBT), Anti maksiat, walaupun cara yang mereka tempuh kadang perlu adanya intropeksi dikarenakan sering melakukan tindakan kekerasan.

\section{GPK Khittah dan Dampak di Pemilu Serenak 2019}

Gerakan Pemuda Ka'bah (GPK) merupakan salah satu 'milisi sipil' underbouw Partai Persatuan Pembangunan (PPP). Secara nasional, GPK didirikan di Jakarta sejak April 1982 dimotori tokoh-tokoh muda DPP-PPP, antara lain Alfian Darmawan, Fauzi AR dan Syukri Fadloli. Beberapa sumber menyebutkan, konon, musisi Rhoma Irama juga ikut membidani lahirnya GPK. Mengenai latar historis GPK, Adaby Darban, sejarahwan UGM yang juga salah seorang penasehat GPK menyebutkan bahwa sebetulnya kalau bicara mengenai GPK tak akan lepas dari PPP. Kelahiran GPK menurutnya berawal dari 
PPP yang merupakan suatu fusi dari pada partai Islam yang kemudian pada zaman Orde Baru merupakan salah satu partai yang di gencet oleh pemerintah. Pada saat itu partai memiliki apa yang disebut Angkatan Muda. Dulu di Yogyakarta pernah didirikan yang dinamakan Hamka (Himpunan Angkatan Muda Ka'bah). Pembentukannya juga minta izin dahulu pada keluarga Buya Hamka. Pak Rusdian Hamka membolehkan pakai nama Hamka, maka disitulah awal berkumpulnya anak-anak muda Ka'bah. Kemudian setelah PPP tidak boleh memakai nama Ka'bah, lambang PPP diganti dengan Bintang. Sejalan dengan itu, "Hamka" juga namanya berubah menjadi Angkatan Muda Partai Persatuan Pembangunan. Kemudian setelah itu, PPP kembali pada azas Islam dan lambangnya memakai Ka'bah lagi. Dari situ lalu generasi mudanya membentuk Gerakkan Pemuda Ka'bah (GPK) yang memang resmi di bawah PPP (Gunawan \& P., 2000)

Dalam wawancara dengan Syukri Fadholi selaku Pendiri dan juga pembina GPK di DIY menjelaskan pembentukkan GPK di Yogyakarta juga didorong oleh kenyataan menurunnya perolehan suara PPP pada pemilu lalu. "Ini telah mendorong angkatan muda untuk menggunakan atau mengedepankan kembali salah satu prinsip-prinsip keislaman dan PPP azasnya Islam, Dalam perkembangan berikutnya, anak-anak muda Yogyakarta banyak juga yang tertarik dan lalu bergabung dengan PPP, yang ditandai dengan menjamurnya laskar-laskar PPP. Dari situlah GPK muncul sebagai salah satu kekuatan anak muda PPP di Yogyakarta.

Baru dalam dasawarsa kedua GPK muncul ke permukaan. Itu pun muncul tidak di Jakarta, tapi di Yogyakarta dengan berbagai polah yang fenomenal. Menurut Ipung selaku Komandan GPK Jetis Berdirinya GPK Yogyakarta merupakan spontanitas dari warga PPP Yogyakarta. Walaupun gerakan ini mempunyai kesamaan nama dengan nama GPK yang ada di daerah lain, itu hanyalah suatu kebetulan saja. Gerakan ini pertama kali muncul di Notoprajan dengan tujuan utama untuk melaksanakan Amar Ma'ruf Nahi Mungkar. Oleh karena itu, visi-misinya diorientasikan untuk berbagai kegiatan postif yang menunjang dakwah Islam. Di samping itu, karena GPK juga merupakan bagian tak terpisahkan dari PPP sebagai organisasi politik, maka visi misi GPK juga diarahkan untuk menopang tujuan politis ini, yakni mencari massa agar simpati pada PPP yang punya misi untuk menjalankan syariat Islam.

Namun demikian, dalam perjalanannya, GPK Yogyakarta seolah jalan sendiri dengan agenda-agenda sendiri, lepas kontrol dari PPP sebagai organisasi induknya, meski secara formal GPK masih mengakui sebagai 'anak' PPP. Berbagai aktivitas GPK Yogyakarta lima tahun terakhir ini lebih kental warna nahyi munkarnya dari pada aktivitas seremonial organisatoris yang menopang agenda PPP.

Lepas kontrol Gerakan Pemuda Ka'bah (GPK) dari PPP terlihat di Pemilu serentak 2019. Gerakan Pemuda Ka'bah melakukan deklarasi GPK Khittah, GPK Khittah ini muncul disebabkan perpecahan yang terjadi di Kubu Partai Persatuan Pembangunan di Nasional. Dan juga munculnya dualisme kepemimpinan di tubuh Partai Persatuan Pembangunan.

Pernyataan dari GPK Khittah ini ditanggapi ini oleh Arsul sani yang di lansir media detik.com menjelaskan bahwa GPK Khittah muncul akibat tidak adanya nama Syukri fadholi pada kepengurusan Partai Persatuan Pembangunan dan munculnya perpecahan di internal Partai (Wildansyah, 2018). 
Dari hasil wawancara dengan Syukri Fadholi merupakan Pembina Gerakan Pemuda Ka'bah menjelaskan bahwa GPK Khitah menyatakan tidak akan mendukung pengurus DPP PPP versi Romahurmuziy ataupun versi Djan Faridz. Pengurus DPP PPP dua kubu itu dinilai sudah menjual partai untuk kepentingan pribadi dan kelompok. Sebagaimana diketahui, GPK Khittah sebagai ormas PPP dalam pemilu 2019 justru menyalurkan hak politiknya kepada Partai Gerindra. Artinya mendukung caprescawapres nomor urut 02 Prabowo-Sandiaga. GPK Khittah ini menyuarakan slogan "Kosongkan Gerbong" artinya untuk tidak memberikan suara kepada PPP. Berikut beberapa bentuk kampanye di media sosial yang dilakukan GPK Khittah untuk tidak mendukung PPP Nasional dan mendukung pasangan Prabowo-Sandiaga:

\section{Gambar 1. Dukungan GPK Khittah terhadap pasangan Prabowo-Sandi}

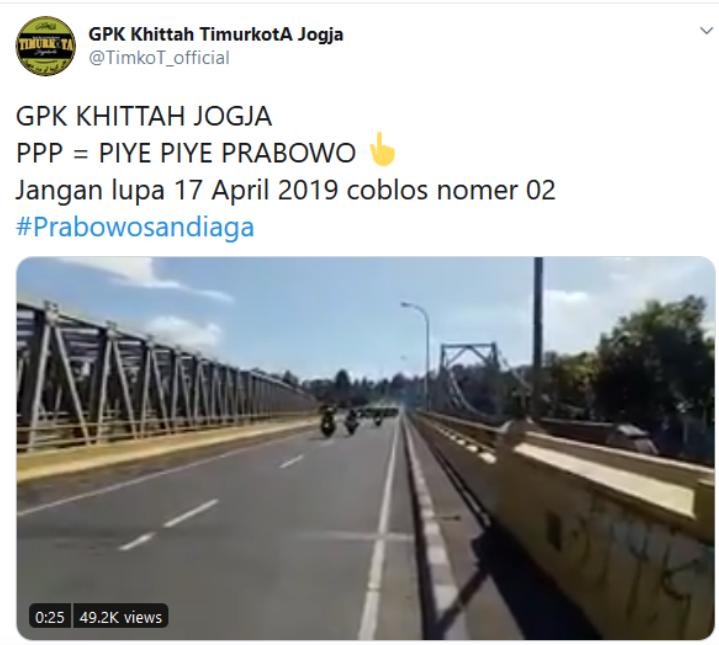

Sumber: Twitter GPK Khittah (@TimkoT_official)

Gambar 2. Dukungan GPK Khittah terhadap pasangan Prabowo-Sandi

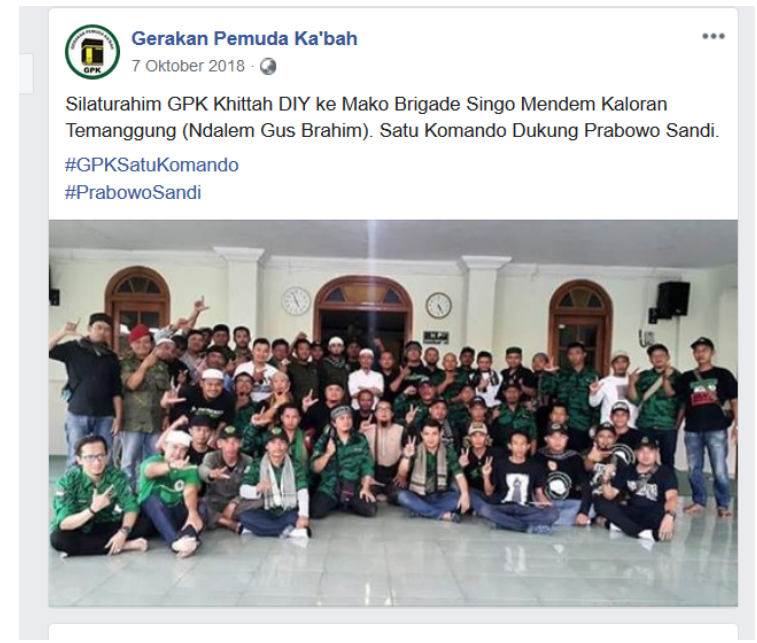

Sumber: Facebook Gerakan Pemuda Ka'bah

GPK Khittah berdampak pada peroleh suara legislatif di Kota Yogyakarta secara keseluruhan. Menurut Data yang dilansir Komisi Pemilihan Umum Kota Yogyakarta 
perolehan kursi pemilihan legislatif 2019 di Kota Yogyakarta, Partai Persatuan Pembangunan Kota Yogyakarta hanya mendapatkan 1 kursi DPRD Kota Yogyakarta. Kursi didapatkan dari caleg petahana M. Hasan Widagdo Nugroho dari daerah pemilihan dapil 5. Sedangkan di tahun 2014 PPP Kota Yogyakarta mendapatkan 4 kursi DPRD Kota Yogyakarta (Saputro, 2016).

Dari hasil wawancara dengan Arief Arjani selaku Tokoh muda Gerakan Pemuda Ka'bah (GPK) yang dilakukan oleh penulis bahwa menurunya suara PPP disebabkan permasalahan internal di tingkat pusat hingga di daerah. Propaganda GPK khittah mendorong terjadinya perpecahan di internal dan mengakibatkan mesin politik tidak berjalan dengan maksimal. Pemilih PPP juga banyak beralih disebakan pemilih PPP ideologis di Kota Yogkarta sangat banyak.

Namun hasil legislatif berbeda dengan hasil pemilihan Presiden dan Wakil Presiden di Kota Yogyakarta berbanding terbalik dengan legislatif. Pasangan calon nomor urut 1 Jokowi-Maruf menang telak di Kota Yogyakarta. Jokowi dan Maaruf Amin unggul dengan suara 179.048, sementara Prabowo dan Sandiaga Uno 92.166 suara.

Deklarasi GPK Khittah ini tidak bisa dipungkiri mengundang para pengamat politik untuk melihat apa tendensi kepentingan dari GPK Khittah untuk mengosongkan gerbong Partai Persatuan Pembangunan yang berdampak pada turunnya suara pemilih legislatif di Kota Yogyakarta dan di seluruh Kabupaten di DIY. Berikut skema dampak dan tujuan GPK Khittah.

Tabel 2. Skema Dampak dan Tujuan GPK Khittah

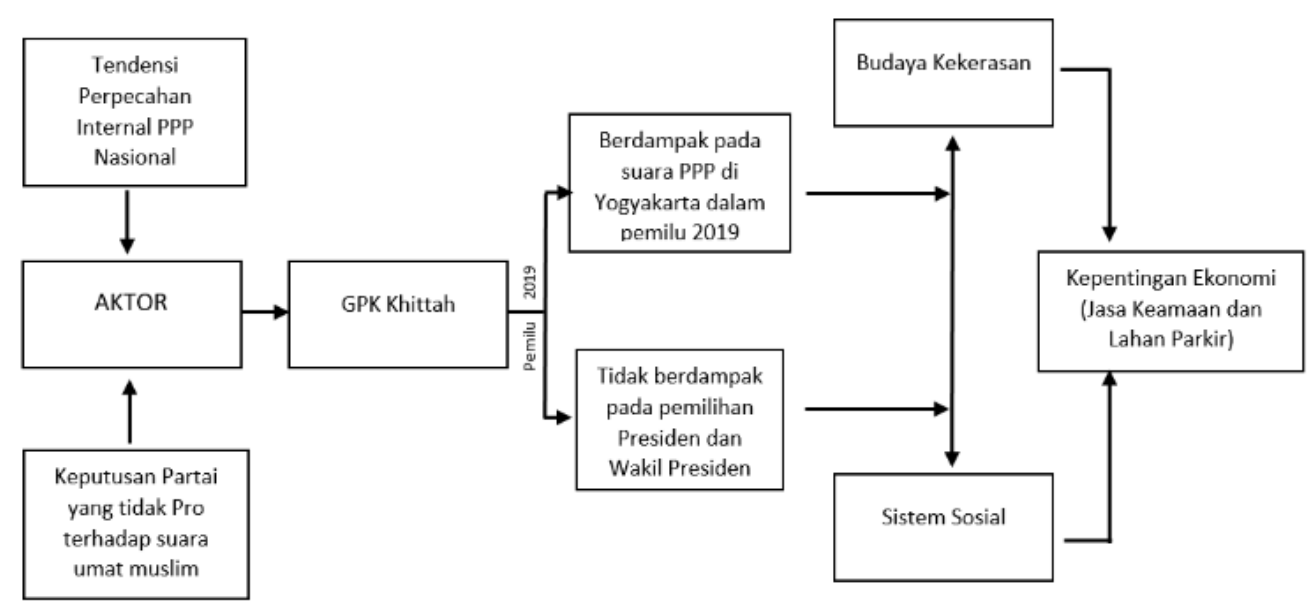

Sumber: diolah oleh penulis

Dalam analisis penelitian ini bahwa GP Khittah didasarkan pada perpecahan internal PPP tingkat Nasional, dimana kepengurusan PPP terjadi dualisme kepemimpinan. Dan PPP tingkat pusat dianggap tidak pro terdapa suara umat islam dan jauh dari nilai-nilai Islam. Inisiasi aktor sentral dalam GPK Khittah ini ialah Syukri Fadholi yang merupakan pembina GPK DIY sekaligus yang dihormati oleh Kelompok GPK. Di Pemilu serentak 2019 bahwa GPK Khittah tidak berdampak pada suara pemilihan eksekutif hanya berdampak pada pemilihan legislatif. Secara basis masa pemilih di Pemilihan umum Gerakan Pemuda Ka'bah tidak memiliki basis masa pemilih yang besar 
namun hanya sebatas simpatisan di jalanan. Orientasi politik Gerakan Pemuda Ka'bah lebih cenderung kepada orientasi politik jalanan dibandingkan penguasaan politik di Legislatif maupun di eksekutif. Prilaku politik jalanan ini memiliki keuntungan ekonomi dengan mengandalkan kemampuan bela diri dan kekerasan dalam penguasaan lahan parkir dan jasa keamanan.

GPK Khittah juga bisa dikategorikan sebagai eksistensi simbol kelompok ini sebaga kelompok Islam dalam melakukan Amar Mahruf Nahi Mungkar, tujuan utamanya juga sebagai kelompok yang memiliki basis masa politik dalam kegiatan kekerasan. Walaupun secara keterwakilan politik di Legislatif tidak memiliki kader di kancah legislatif, Gerakan Pemuda Ka'bah merupakan kelompok yang masih diperebutkan oleh para aktor politik lokal sebagai basis jasa keamanan dan basis kepetingan politik.

Fenomena ini selaras dengan temuan Vickers (2013) menjelaskan bahwa pasca orde baru ideologi dan simbolisme dari banyak "penguasaha kekerasan" mulai bergeser dari ideologi dan simbolisme yang terkait dengan gambaran negara yang statis dan semakin banyak diambil dari identitas-identitas teritorial yang bersifat komunal dan subnasional. Kepetingan predatoris berkelindan dengan klaim-klaim hak dari berbagai kelompok etnis dan komunal serta agenda-agenda "moral' kebangkitan Islam politik.

\section{Penutup}

Di Indonesia para spesialis kekerasan non-pemerintah sudah menjadi sosok yang nyata hadir di sepanjang sejarah muktahirnya maupun pada waktu yang lebih lampau. Gerakan Pemuda Ka'bah dianggap sebagai sebuah kelompok yang memiliki tendensi kekerasan dalam aksi-aksi atau tindakan politik. Kelompok ini hadir dengan varian yang disebut kelompok ormas-ormas vigilante dan milisi. Gerakan Pemuda Ka'bah sejak didirikan sesungguhnya sebagai anak dari Partai Persatuan Pembangunan yang bertujuan untuk menarik suara pemilih muda dalam setiap ajang pemilihan umum baik pemilihan legislatif dan eksekutif maupun pemilihan kepala daerah.

Bentuk tindakan Gerakan Pemuda Kabah ini untuk memperjuangkan eksistensi dan identitas simbol politiknya di masyarakat Yogyakarta mencakup beberapa isu. Mulai dari politik, sumber ekonomi sampai dengan isu keagamaan. Pada wilayah politik Gerakan Pemuda Ka'bah selalu aktif ketika penyelenggaraan pemilu baik legislatif dan eksekutif. Kemudian pada isu ekonomi mereka terlibat dan dapat mengelola beberapa sumber-sumber ekonomi yang ada pada wilayah Kota Yogyakarta, seperti pengelolaan lahan parkir, lapak-lapak sekaten, jasa keamanan. Pada isu agama pun mereka juga terlibat aktif seperti parade tauhid, gerakan anti Syi'ah, Sweeping tempat maksiat. Tindakan-tindakan mereka ini bagian untuk menunjukan eksistensi simbol islam kepada masyarakat luas.

Stigma masyarakat tentang Gerakan Pemuda Ka'bah ini menuai pro dan kontra, dikarenakan aksi-aksi tindakan politik jalanan kerap melakukan tindakan kekerasan fisik yang meresahkan masyarakat. Tindakan mereka memberikan semangat kepada sebagian masyarakat, minimal pada anggota Gerakan Pemuda Ka'bah untuk senantiasa menjaga kehormatan martabat agama Islam, seperti penolakan tentang legitimasi Lesbi, Biseksual, Gay, Trans Gender (LGBT), Anti maksiat, walaupun cara yang mereka tempuh kadang perli adanya intropeksi dikarenakan sering melakukan tindakan kekerasan. 
Hasil penelitian ini menunjukan bahwa Prilaku kekerasan Politik jalanan Gerakan Pemuda Ka'bah didasari pada kepentingan ekonomi. Prilaku politik jalanan digunakan sebagai ajang untuk menunjukan eksistensi simbol sebagai kelompok yang kuat dan berazaskan Islam. Prilaku ini mendorong terjadinya hubungan patron-klien antara elite politik lokal dan elite GPK. Prilaku politik Gerakan Pemuda Ka'bah lebih condorong kepada orientasi kekerasan dengan tujuan sebagai mengelolah wilayah dan jasa keamanan dibandingkan politik elektoral. Selanjutnya munculnya deklarasi GPK Khittah yang di dasari oleh perpecahan internal Partai Persatuan Pembangunan di nasional. GPK Khittah mengakibatkan suara pemilih PPP di pemilu 2019 menjadi menurun di Kota Yogyakarta bahkan di seluruh wilayah Kabupaten di Daerah Istimewa Yogyakarta. Namun GPK Khittah tidak berdampak pada pemilihan Presiden dan Wakil Presiden. Tidak adanya keterwakilan politik Gerakan Pemuda Ka'bah di legislatif dan eksekutif tidak mengakibatkan turunnya eksitensi kelompok ini. Kehadiran kelompok ini masih di gunakan sebagai kepentingan perlindungan "jasa keamanan" dan pengelolahan lahan parkir atau kepentingan politik lainnya. Orientasi politik kelompok ini tidak kepada politik parlemen tapi lebih kepada politik mobilisasi jalanan dan kekerasan.

Saran penelitian ini ialah penting bahwa kelompok ini mulai memikirkan merebut kursi politik di pemilihan kepala daerah dan juga pemilihan legislatif agar keterwakilan politik mereka tersalurkan dalam ranah kepentingan politik yang lebih luas dan bermanfaat. Tentunya perlu merubah citra Gerakan Pemuda Ka'bah sebagai kelompok yang lembut dan moderat serta mencirikan nilai-nilai Islam yang halus dan akomodatif agar mendapatkan dukungan positif oleh masyarakat.

\section{Ucapan Terima Kasih}

Kami mengucapkan terimakasih kepada para informan, diantaranya Arief Arjani, Ipung, dan Syukri Fadholi yang telah berkenan menjadi informan penelitian ini dan membantu menjelaskan secara spesifik dalam proses observasi lapangan.

\section{Pendanaan}

Penulis tidak menerima bantuan pembiayaan untuk penelitian, kepenulisan (authorship), dan publikasi dari pihak manapun.

\section{Daftar Pustaka}

Berenschot, W. (2018). The political Economy of Clientelism: A Comparative Study of Indonesia's Patronage Democracy. Comparative Political Studies, 51(12), 15631593. https://doi.org/https://doi.org/10.1177/0010414018758756

Budiardjo, M. (2010). Dasar-Dasar Ilmu Politik. Jakarta: Gramedia Pustaka Utama.

Buur, L., \& Jensen, S. (2004). Introduction: Vigilantism and the Policing of Everyday Life in South Africa. African Studies, 63(2), 139-152.

Centeno, M. A., \& Portes, A. (2006). The Informal Economy in the Shadow of the State. Out of the Shadows: Political Action and the Informal Economy in Latin America, 23-48.

Colombijn, F. (2002). Explaining the Violent Solution in Indonesia. The Brown Journal of World Affairs, 9(1), 49-56.

Creswell, J. W. (2016). Research Design: Pendekatan Metode Kualitatif, Kuantitatif, dan 
M. E. T. Pahlevi, D. Efendi, \& A. A. Amrurobbi I Politik Jalanan: Fenomena Perilaku Politik Gerakan...

Campuran. Yogyakarta: Pustaka Pelajar.

Efriza. (2019). Eksistensi Partai Politik Dalam Persepsi Publik The Existence of The Political Parties in Public Perception. Jurnal Politica, 10(1), 17-38. https://doi.org/10.22212/jp.v10i1.1314

Gunawan, F. R., \& P., N. (2000). Premanisme Politik, ISAl, Jakarta bekerja sama dengan LKiS Yogyakarta. Yogyakarta: LKiS.

Heywood, A. (2007). Politics. New York: Palgrave Macmillan.

Laksono, P. M., Brata, N. T., Ertanto, K., Riomandha, T., \& Gunawan. (2000). Permainan Tafsir: Politik Makna di Jalan pada Penghujung Orde Baru. Yogyakarta: Insist.

O'neil, T., \& Domingo, P. (2016). Women and Power: Overcoming Barriers to Leadership and Influence. London: Overseas Development Institute.

Saputro, T. (2016). Politik Jalanan \& Kaum Muda: Studi Tentang Gerakan Pemuda Ka'bah (GPK) di Kota Yogyakarta. Yogyakarta: UIN Sunan Kalijaga Yogyakarta.

Surbakti, R. (2010). Memahami Ilmu Politik. Yogyakarta: Grasindo.

Vickers, A. (2013). A history of Modern Indonesia. Cambridge University Press.

Wildansyah, S. (2018). PPP Ungkap Alasan Kader "Khittah" Yogya Dukung Prabowo. Retrieved from https://news.detik.com/berita/d-4250919/ppp-ungkap-alasankader-khittah-yogya-dukung-prabowo

Wilson, I. D. (2015). The Politics of Protection Rackets in Post-New Order Indonesia: Coercive Capital, Authority, and Street Politics. Abdingdon: Routledge.

Wilson, I. D. (2018). Politik Jatah Preman: Ormas dan Kuasa Jalanan di Indonesia Pasca Orde Baru. Marjin Kiri.

Yasih, D. W. P. (2015). Tradisi, Ekonomi-Politik, dan Toleransi Yogyakarta. MASYARAKAT: Jurnal Sosiologi, 147-171.

\section{Daftar Informan}

Arief Arjani, Pimpinan Tokoh Muda Gerakan Pemuda Ka'bah Yogyakarta, 12 september 2019, pukul 13.00 WIB.

Ipung, Komandan Pimpinan Gerakan Pemuda Kab'ah Jetis Yogyakarta, 20 April 2018, Pukul 20.00 WIB.

Syukri Fadholi, Pembina dan Pendiri Gerakan Pemuda Ka'bah, 30 Maret 2019, Pukul 19.30 WIB.

\section{Tentang Penulis}

Moch Edward Trias Pahlevi adalah alumni Magister Ilmu Pemerintahan, Universitas Muhammadiyah Yogyakarta. Penulis memiliki ketertarikan studi seputar tema pemilu, demokrasi, politik lokal, kekerasan politik.

David Efendi adalah dosen Magister Ilmu Pemerintahan yang mengampu mata kuliah terkait dengan ekologi, civil society, dan kajian demokrasi.

Azka Abdi Amrurobbi adalah mahasiswa Magister Politik Pemerintahan, konsentrasi Tata Kelola Pemilu, Universitas Gadjah Mada. Penulis memiliki ketertarikan studi terkait dengan tema tata kelola pemilu, kelompok marjinal, dan demokrasi. 